\title{
Bergmann Glia, Long-Term Depression, and Autism Spectrum Disorder
}

\author{
Adrian Andrzej Chrobak ${ }^{1,2} \cdot$ Zbigniew Soltys $^{1}$
}

Received: 16 October 2015 / Accepted: 12 January 2016 / Published online: 26 January 2016

(C) The Author(s) 2016. This article is published with open access at Springerlink.com

\begin{abstract}
Bergmann glia (BG), a specific type of radial astrocytes in the cerebellum, play a variety of vital functions in the development of this structure. However, the possible role of $\mathrm{BG}$ in the development of abnormalities observed in individuals with autism spectrum disorder (ASD) seems to be underestimated. One of the most consistent findings observed in ASD patients is loss of Purkinje cells (PCs). Such a defect may be caused by dysregulation of glutamate homeostasis, which is maintained mainly by BG. Moreover, these glial cells are involved in long-term depression (LTD), a form of plasticity which can additionally subserve neuroprotective functions. The aim of presented review is to summarize the current knowledge about interactions which occur between PC and BG, with special emphasis on those which are relevant to the survival and proper functioning of cerebellar neurons.
\end{abstract}

Keywords Neuroglia $\cdot$ Plasticity $\cdot$ Radial glia .

Excitotoxicity $\cdot$ Glutamate transporters

\section{Introduction}

The cerebellum is well known for its role in motor behavior. Moreover, there is growing evidence that this part of the brain is involved in various cognitive and affective processes $[1,2]$ and

Adrian Andrzej Chrobak

adrian.andrzej.chrobak@gmail.com

1 Department of Neuroanatomy, Institute of Zoology, Jagiellonian University, Gronostajowa St. 9, Cracow 30-387, Poland

2 Faculty of Medicine, Jagiellonian University Medical College, Kopernika St. 21A, Cracow 31-501, Poland that its dysfunctions may be linked to various psychiatric disorders [3], including autism spectrum disorder (ASD) [4, 5].

The characteristic features of this syndrome such as deficit in social interactions or hypersensitivity to sensory stimuli [6] indicate the cerebral cortex as a potential locus of pathology. Nevertheless, significant anatomical pathology can also be seen in the cerebellum of ASD patients, including a reduction in the total volume, atrophy of the folia, [7, 8], and small foci of dysplasia [9]. Loss of Purkinje cells (PCs), the principal neurons in the cerebellum, is the most consistent cellular abnormality found in ASD [10, 11]. Importantly, this deficit has not resulted from decreased proliferation but from the loss of the PC in the later stages of development [12].

Bergmann glia (BG) is a type of radial glia specific for the cerebellum. While BG somata are localized in the Purkinje cell layer, their processes form a dense palisade extending through molecular layer of the cortex. Similar to protoplasmic astrocytes in other parts of the brain, BG processes cover synapses on Purkinje neuron dendrites [13], what suggests its participation in the regulation of synaptic transmission. Paradoxically, BG is the most ignored population of cerebellar cells. It is hard to find these cells in the textbook diagrams depicting the structure of the cerebellar cortex connections. Although each $\mathrm{PC}$ is linked to $\mathrm{BG}$, the number of publications related to this glia is only 5-6\% of those on PC (according to Pubmed and Google Scholar search).

In this paper, we will present arguments in favor of the hypothesis that abnormalities in the interaction between BG and PC may lead to the emergence of autism spectrum disorders. First of all, we will briefly summarize our knowledge about the role of BG in the development and maintenance of the proper functioning of the cerebellum, with particular focus on glutamatergic transmission. Then, we will discuss the involvement of these cells in long-term depression (LTD). This phenomenon is usually regarded as a basic mechanism of 
cerebellar-dependent learning; however, it was also proposed that LTD serves a neuroprotective functions [14]. In the last part, we consider the possible causes of abnormal interactions between cerebellar cells and the effects of these anomalies for the functioning of the entire brain.

\section{Bergmann Glia and Purkinje Cell Interactions}

BG play crucial role in regulation of cerebellum development-migration, cells' maturation, and synaptogenesis [15-20].

On the other hand, BG requires continuous association with $\mathrm{PC}$ for the development of its own normal phenotype. For example, the presence of $\mathrm{PC}$ is necessary to maintain high levels of sn-glycerol-3-phosphate dehydrogenase - an enzyme involved in several metabolic pathways including lipid synthesis and energy metabolism [21]. Dynamic transformation of BG fibers and the expression of the glutamate transporter (GLAST) correlate with dendritic outgrowth and synapse formation of cerebellar PC [22]. Neuron-derived fibroblast growth factor 9, neuron-specific Delta/Notch-like EGF-related receptor, and sonic hedgehog protein are vital for mediating neuron-glia interaction and promote differentiation of BG and its GLAST expression [23-26].

Interactions between $\mathrm{BG}$ and neurons are very complex. Tables 1 and 2 present known elements of BG interactome. List of receptors reveals that these glial cells can react to numerous neurotransmitters, not only for those released by cerebellar neurons. On the other hand, action of BG gliotransmitters is not limited to PC. However, detailed discussion on these interactions is beyond the scope of this article.

\section{Clearing of Glutamate}

Causes of PC degeneration in ASD are still not fully understood. One of the most common causes of neuronal death is elevated extracellular glutamate level [55-57].

EAAT1 (GLAST) and EAAT2 (GLT-1) are astroglial transporters responsible for more than $80 \%$ of total glutamate uptake in the CNS [58-60]. Reduction of GLAST and GLT-1 expression results in increased extracellular glutamate level and excitotoxicity leading to severe neurodegeneration [61].

GLAST stands for majority of glutamate transporters in the cerebellum; its amount is six times higher than GLT-1 and ten times higher than neural glutamate transporterEAAT4 $[62,63]$. The highest density of GLAST is presented in BG where it reaches $\sim 18,000$ molecules per $\mu \mathrm{m}^{3}$ $[62,63]$. GLAST-deficient mice present mild motor discoordination and increased cerebellar damage after cerebellar injury [64]. Lack of this transporter affects also PC innervation pattern, resulting in higher number of PC
Table 1 Bergmann glia receptors

\begin{tabular}{|c|c|c|}
\hline Agonist & Bergmann glia receptors & References \\
\hline Glutamate & $\begin{array}{l}\mathrm{Ca}^{2+} \text {-permeable AMPAR, } \\
\text { mGluR1, mGluR5 }\end{array}$ & [27] \\
\hline Purines & P2Y, P2X7 & [28] \\
\hline Serotonin & 5-HT2A & [29] \\
\hline Noradrenaline & $\alpha 1 \mathrm{~A}$ & {$[30]$} \\
\hline Histamine & $\mathrm{H} 1$ & [31] \\
\hline Acetylcholine & M2 & [32] \\
\hline GABA & $\mathrm{GABA}_{\mathrm{A}}, \mathrm{GABA}_{\mathrm{B}}$ & [33] \\
\hline $\mathrm{CRF}$ & CRF-R1, CRF-R2 $\alpha$ & [34] \\
\hline Endothelin & ETB & {$[35]$} \\
\hline T3 & $\mathrm{TR} \alpha 1$ & [36] \\
\hline BDNF & TrkB & [37] \\
\hline Angiotensin II & AT1R & [38] \\
\hline VEGFR & VEGFR-3 & [39] \\
\hline HGF & c-Met-IR & {$[40]$} \\
\hline CGRP & CGRPR & [41] \\
\hline $\begin{array}{l}\text { Pathogen-associated } \\
\text { molecules }\end{array}$ & Toll-like receptor 3 & [42] \\
\hline Melatonin & MT2 & [43] \\
\hline Chemokines & CCR1 & [44] \\
\hline PTN & $\mathrm{PTP} \zeta$ & {$[45]$} \\
\hline $\begin{array}{l}\text { Delta } \\
\text { Delta-like } 1\end{array}$ & Notch1, Notch2 & {$[25,46]$} \\
\hline \multicolumn{3}{|l|}{ DNER } \\
\hline FGF & FGFR1 & [47] \\
\hline Shh & ShhR & [24] \\
\hline
\end{tabular}

multiply innervated by climbing fibers (CF) in comparison to the wild-type mice [64]. Pharmacological blockade of these transporters prolongs PC $\alpha$-amino-3-hydroxy-5methyl-4-isoxazolepropionic acid receptor (AMPAR)-mediated excitatory postsynaptic current (EPSC) after both $\mathrm{CF}$ and parallel fiber (PF) stimulation and favors glutamate spillover into neighboring synapses [65]. Those observations indicate that GLAST plays an essential role in
Table 2 Substances released from Bergmann glia

\begin{tabular}{ll}
\hline $\begin{array}{l}\text { Substances released } \\
\text { from Bergmann glia }\end{array}$ & References \\
\hline D-Serine & {$[48]$} \\
L-Glutamate & {$[49]$} \\
L-Glycine & {$[50]$} \\
GABA & {$[51]$} \\
Taurine & {$[52]$} \\
S100B & {$[53]$} \\
PTN & {$[45]$} \\
Gdf10 & {$[24]$} \\
Il-1 $\beta$ & {$[54]$} \\
\hline
\end{tabular}


establishing morphological and functional one-to-one relationship between $\mathrm{CF}$ and PC [66].

Despite the fact that GLAST expression is sixfold higher than GLT-1 [63], GLAST knockout mice exhibit only minor motor discoordination [64] and reveal no significant alteration of CF-mediated EPSC in PC [67, 68]. Also, deletion of GLT-1 alone does not significantly affect cerebellar development [69]. However, knockout of both GLAST and GLT-1 disrupts cerebellar folium formation and results in prenatal death [70, 71]. This raises a possibility that GLT-1 may compensate for the downregulation or loss of the GLAST [71].

\section{GLAST in Direct Intracellular Signaling}

GLAST may play an active role in direct intracellular signaling. In cultures of chick BG, glutamate triggers two temporally separated pathways affecting GLAST functions. In the "early" pathway, glutamate uptake by GLAST activation triggers $\mathrm{Na}^{+}$influx that stimulates $\mathrm{Na}^{+} / \mathrm{Ca}^{2+}$ exchanger resulting in $\mathrm{Ca}^{2+}$ influx. This process leads to inhibition of GLAST translation (through mTOR pathway) and to downregulation GLAST expression in plasma membrane (through cytoskeletal re-arrangements). In the "late" pathway, glutamate binding to its receptors downregulates GLAST transcription in $\mathrm{Ca}^{2+}$ / PKC-dependent manner [72].

What is intriguing in these findings is that glutamate action leads to downregulation of its own transporters, resulting in an inhibition of anti-excitotoxic system. The BG reaction to glutamate appears to be different to that observed in astrocytes, in which glutamate upregulates GLAST activity [73, 74]. However, these observations should be confirmed with further studies, at least in mixed cultures in which BG would be in contact with neural cells.

\section{AMPAR on BG}

BG is involved in glutamate signaling not only by glutamate transporters but also by its expression of $\mathrm{Ca}^{2+}$-permeable AMPAR. This type of AMPA receptors contains GluA1 and GluA4 subunits. In the adult cerebellum, GluA1 subunit is exclusively localized to BG [75]. Conversion of those receptors into $\mathrm{Ca}^{2+}$-impermeable type by delivery of GluA2 gene results in retraction of the glial processes from PC. Retraction of the glial processes (with its glutamate transporters) results in increase in the distance between PC and BG membranes. This leads to similar consequences as GLAST (-/-) mutation in mice model: multiple innervation of $\mathrm{PC}$ by $\mathrm{CF}$ and impaired uptake of glutamate in both CF and PF synapses [76]. Consistently, overexpression of calcium-permeable AMPAR resulted in elongation of processes [77]. Further in vivo studies confirmed that mice knockout for AMPAR revealed similar retraction of BG processes and altered clearance of glutamate resulting in disrupted duration and decay of PF-evoked
PC EPSCs. Furthermore, mice showed deficits in motor functions and motor learning [78].

Activation of AMPAR inhibits $\mathrm{K}^{+}$conductance of the glia [79] likely due to the inhibition of gap junctional coupling [80]. In cultured chick cerebellar BG, AMPAR has also been shown to participate in downregulating transcription of GLAST [81].

Importantly, BG AMPAR are not activated "classically" by glutamate spillover from synaptic cleft but through specially dedicated extrasynaptic release sites (Fig. 1) [82-84], which exhibit a form of frequency-dependent plasticity due to the lack of fast vesicle recycling mechanism. Thus, during repetitive stimulation, exhaustible pool of vesicles in ectopic sites become depleted, resulting in the lack of glutamate released into BG-enriched AMPAR sites (Fig. 1) [85]. Repetitive stimulation of CF or PF at $0.1-1 \mathrm{~Hz}$ results in "long-term depression of neuron to glia transmission," reducing $\mathrm{Ca}^{2+}$ currents in BG. This depression becomes persistent when PF stimulation reaches more than a few minutes, leading to inhibition of AMPAR $\mathrm{Ca}^{2+}$ currents [86]. This plasticity is not only activity-dependent but also input-specific because $\mathrm{CF}$ and $\mathrm{PF}$ inputs can be independently depressed [86].

\section{Cerebellar Long-Term Depression}

LTD refers to the long-term attenuation of neurotransmission within the synapse after prolonged stimulation with an appropriate pattern. In the cerebellum, LTD occurs at excitatory synapses between PC and PF. Single PC receives excitatory glutamatergic input from hundreds of $\mathrm{PF}$ and from one CF. LTD is induced by simultaneous and repetitive stimulation from parallel and $\mathrm{CF}$ or by particular input from PF alone $[87,88]$. LTD is expressed as long-term attenuation of glutamatergic transmission in PF-PC synapses by internalization of AMPAR in PC [87].

In 1997, Llinas et al. [14] proposed that LTD does not reflect motor learning process but a neuroprotective function defending PC from $\mathrm{Ca}^{2+}$ mediated excitotoxicity. One PC forms approximately 500 glutamatergic synapses with one CF [89] and up to 200,000 with PF [90], which situate PC at constant risk of $\mathrm{Ca}^{2+}$ influx from permanent synaptic bombardment. Overwhelming intracellular $\mathrm{Ca}^{2+}$ elevation leads to PC death or damage of its dendritic arbor. LTD occurs as a result of excessive excitation of $\mathrm{PC}$ and through the rise of intracellular $\mathrm{Ca}^{2+}$ leads to PKC activation, phosphorylation of AMPAR, and its internalization [14, 87]. Thus, LTD results in decreased responsiveness of PC to further glutamate stimulation [14]. However, this alternative view of LTD as a damage control mechanism did not achieve adequate attention. Despite experiments indicating that cerebellum-dependent learning such as eyeblink conditioning can actually be performed in mouse models lacking of LTD [91, 92], this 
Fig. 1 Bergmann glia interactions

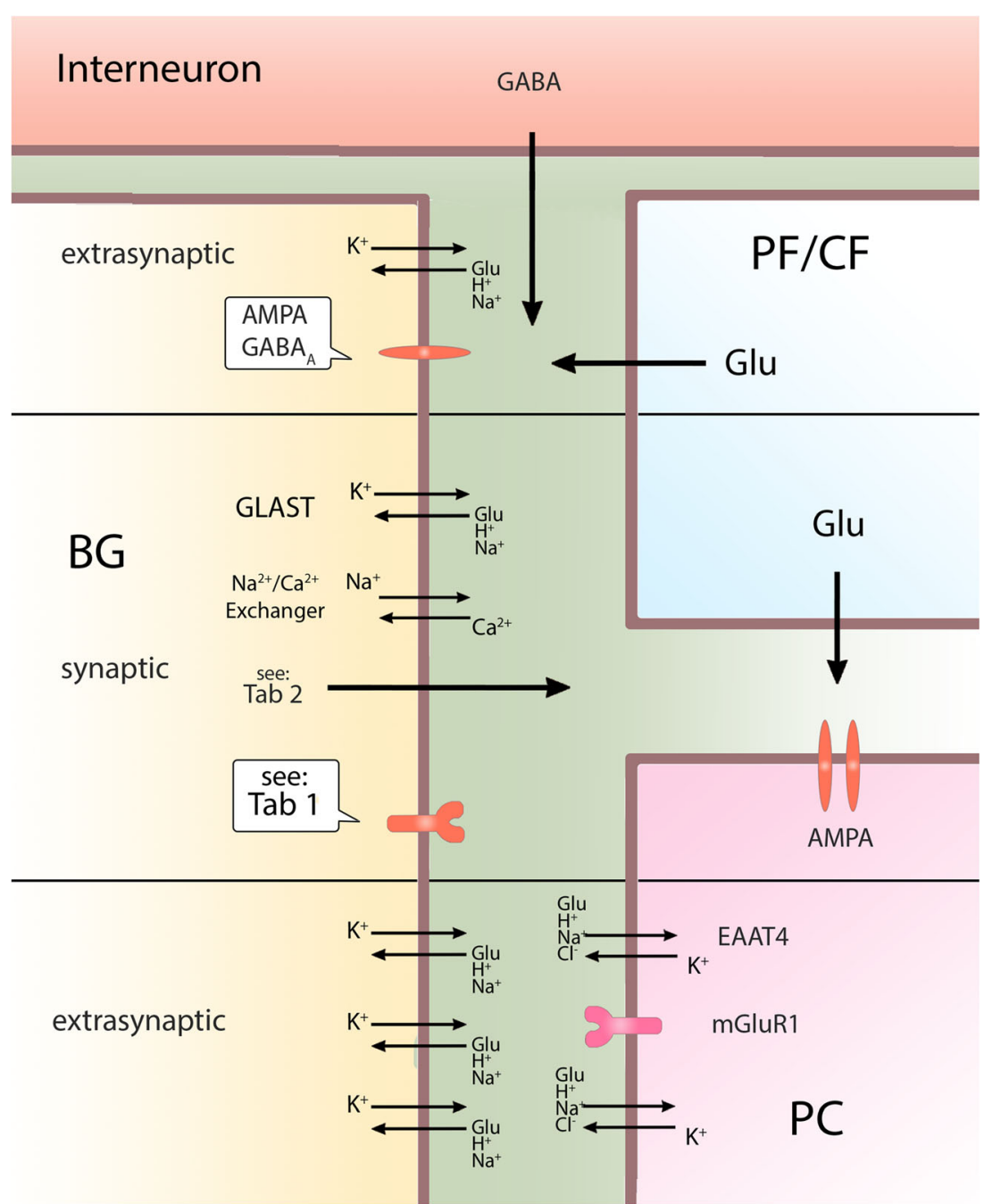

phenomenon is still regarded mainly as a cellular substrate of cerebellar motor learning [93].

Shibuki et al. [94] demonstrated one of the first pieces of evidence that LTD requires BG, using mice devoid of glial fibrillary acidic protein (GFAP). This cytoskeletal protein is highly expressed in BG [94]. GFAP-deficient mice present impaired cerebellar LTD. This abnormality was not related to changes in synapse number or shape, altered protein expression, impairments in transmission of PF and CF, nor alterations in BG morphology [94]. The results indicated GFAP as a significant factor, needed for proper communication between BG and PC, enabling occurrence of LTD. GFAP may affect glutamatergic signaling because GFAP-null mice presented upregulation of both total and synaptosomal levels of EAAT2 protein in cerebellum [95]. It has been proposed that increased EAAT2 expression may limit LTD response by facilitating uptake of glutamate [95].

Importantly, stimulation of $\mathrm{CF}$ and $\mathrm{PF}$ at $1 \mathrm{~Hz}$ in order to evoke LTD in PC resulted in long-term depression of AMPAR currents in BG from both inputs [86]. Thus, during LTD, BG AMPAR is probably paradoxically cut off from their main source of glutamate. So, if the mechanism of AMPAR-derived downregulation of GLAST also exists in vivo, this would mean that during LTD, this process will be inhibited. This inhibition would avoid initiating GLAST reduction during states that threaten excitotoxicity and favor signaling involved in GLAST upregulation. Consistently, Balakrishnan et al. [85] suggests that glutamate is released from ectopic sites of fibers which are firing unusually slowly. Those fibers alert BG through AMPAR, resulting in encompassing of those faulty connections by BG processes. Probably, GLAST downregulation occurs in those synapses leading to strengthening of glutamate transmission.

Another mechanism involved in BG AMPAR regulation relies on the control of neuronal glutamate transporter, EAAT4, which represents one of the smallest fraction of glutamate transporters in cerebellum [63]. EAAT4 are expressed in $\mathrm{PC}$, with the highest density in the dendritic and spine membranes facing BG (Fig. 1) [96]. EAAT4 is likely to affect 
extrasynaptic but not synaptic glutamate concentration [97]. Interestingly, higher expression of EAAT4 is inversely correlated with a degree of BG AMPAR activation after PF stimulation [97]. This could result in different BG AMPAR activation in regions with high or low expression of EAAT4, leading to differences in the level of encompassing PC synapses by BG processes in those regions [97]. This could affect regional differences in innervation of PC by CF, and GLAST regulation, which can correspond with the fact that variations in EAAT4 expression contribute to PC vulnerability to excitotoxic death [98]. The role of EAAT4 in regulating the structure of BG processes is enforced by the observation that in mice, its expression rises after birth, reaching maximum at the third week of age which corresponds to the time of maturation of BG ensheathment to PC synapses [97]. Additionally, EAAT4 are expressed closely to PCs' mGluR1 receptors, which are crucial for LTD [99]. It has been shown that inhibition of EAAT4 facilitates cerebellar synaptic LTD, indicating its important role in plasticity [100].

Sasaki et al. [49] showed that the role of BG in LTD may be far more active than we thought. Photostimulation of BG in transgenic mice expressing channelrhodopsin-2 specifically in those cells resulted in an increase in extracellular $\mathrm{K}^{+}$, release of glutamate, and inducing LTD at PFPC synapses. Glutamate released from BG activated mGluR1 on PC [49], which is essential for inducing this form of synaptic plasticity [101]. Processes of BG are located immediately adjacent to the mGluR1 on PC (Fig. 1) in the areas highly protected by neuronal glutamate transporters [102]. This arrangement raises a possibility that summation of glutamate from neuronal spillover and glial release may be required to overcome this protection to activate the mGluR1 [49] and enables glutamate originating from glia to act safer, by more direct action on the specific area covered with those receptors. A fact that stimulation of BG was sufficient factor to evoke LTD emphasizes important role of this cell in LTD and cerebellar functions.

PCs have specific orphan receptors GRID2 ( $\delta 2$ glutamate receptor, GluD2). Mutations in GRID2 gene were associated with ASD [103] (Table 3). These receptors are necessary for induction of LTD in the cerebellum (but not in the other parts of brain) [118]. Despite its name, GRID2 does not actually bind glutamate. Kakegawa and coworkers [119] have shown that Dserine may be an endogenous ligand for these receptors. It is derived mainly from BG after burst stimulation of PF in immature cerebellum [119]. Glutamate has been shown to activate $\mathrm{BG}$ serine racemase (which converts L-serine to D-serine) through AMPA receptors via glutamate receptor-interacting protein (GRIP) [120]. GRIP binds to serine racemase, enhancing its activity and release of Dserine [120]. Activation of GRID2 by D-serine results in rapid endocytosis of AMPA receptors and depressed excitatory postsynaptic currents in PC [119]. This process may stand for additional neuroprotective mechanism inducing LTD during early postnatal period.

\section{Bergmann Glia and ASD}

Reviewed studies indicate that BG is an important element of the system responsible in evoking LTD. Since BG functions and its participation in LTD exhibit neuroprotective effects, dysfunction of this system may contribute to development of various pathologies, including, inter alia, ASD.

Vulnerability of PC cells has been proposed to play a role in the etiology of ASD [57]. The hypothesis that dysregulation of glutamate transporters is one of the leading causes of neuronal dysfunction in those patients [56] corresponds with clinical observations which have shown that glutamate antagonists may reduce autistic symptoms [121]. ASD patients show that increased blood glutamate level correlated positively with increased glutamate level in the left cerebellum [122]. Several glutamate neurotransmitter system abnormalities have been found in cerebellum of individuals with ASD. Glutamic acid decarboxylase 65 and $67 \mathrm{kDa}$, the enzymes that catalyze decarboxylation of glutamate to GABA are significantly reduced in cerebellum and parietal cortex of ASD patients [123]. Postmortem samples revealed increased levels of EAAT1 and 2. Interestingly, EAAT1 protein increased threefold in autism cerebellum compared with controls. Those changes may reflect reaction due to elevated extracellular glutamate concentration. Furthermore, patients with ASD revealed significantly decreased level of AMPAR density, despite increased messenger RNA (mRNA) of GluA1. Those alterations may be associated with increased levels of proteins associated with AMPAR: GRIP and protein of band 4.1N [55].

4.1N and GluA1 reveal similar spatiotemporal pattern of expression. Both proteins are colocalized in intracellular organelles and cytoskeleton of BG [75], and they may form trimeric complex to regulate AMPAR localization and immobilization [75, 124]. Expression of $4.1 \mathrm{~N}$ in BG becomes detectable when BG wraps PC [75]. A possible interpretation of this observation is that despite a global decrease in AMPAR density in ASD cerebellum, upregulated 4.1N and GluA1 may represent specific increase of AMPAR in BG.

Studies concerning participation of glia in cerebellar pathology in autism are scarce. Some of them indicate absence of glial hyperplasia [125, 126]; others reveal the presence of slight Bergmann gliosis and increase in GFAP level [127, 128]. Purcell et al. [55] identified increase in GFAP mRNA in patients' cerebellum. Recent study reports over twofold higher expression of GFAP in cerebellum of individuals with ASD than in healthy controls providing evidence for astroglial reaction [129]. GFAP level has been found to be three times 


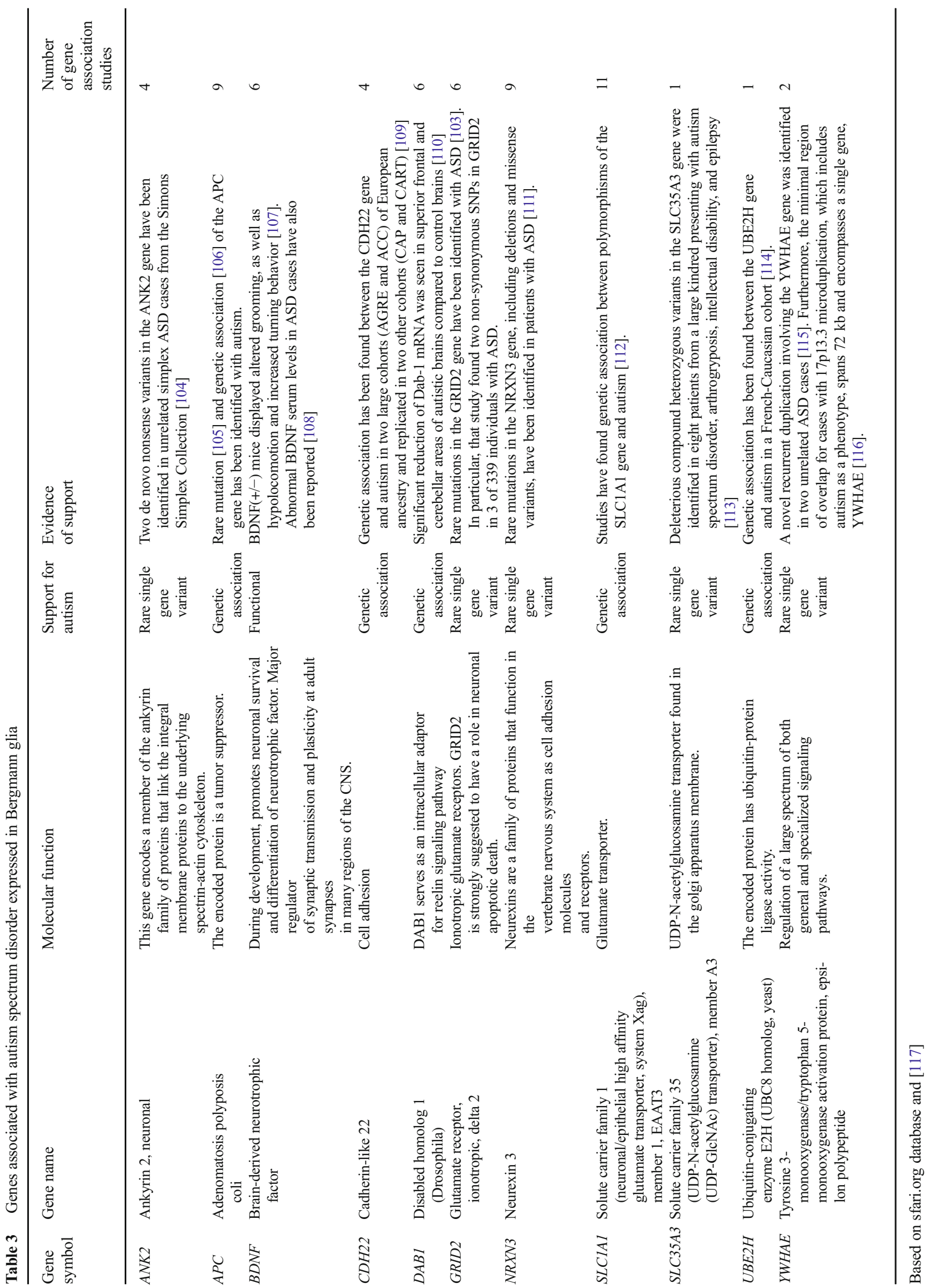


higher in cerebrospinal fluid (CSF) of ASD patients in comparison to healthy controls [130]. Additionally, increased incidence of GFAP autoantibodies was found in ASD [128]. Due the fact that GFAP seems to be associated with regulation of glutamate transporters, it is likely that dysregulation of GFAP expression may contribute to glutamate system abnormalities [95].

Also, a decrease in astrocytic aquaporin 4 (AQP4), a transmembrane water channel protein, has been reported in cerebellum of autistic patients [131]. It has been shown that this protein is crucial for recently described mechanism of brain parenchyma clearance (so-called glymphatic system [132]). According to experiments of Illif et al. [132], cerebrospinal fluid enters the parenchyma along perivascular spaces that surround penetrating arteries. Knockout in Aqp4 gene results in $\sim 70 \%$ reduction in efficiency of this mechanism [132]. Thus, it is possible that decreased aquaporin 4 in cerebella of ASD patients may contribute to disrupted interstitial solute clearance in this brain region, alternating extracellular levels of substances involved in neurotoxicity.

Transcriptional profiling of BG [117] revealed that those cells express several genes associated with ASD (Table 3). Many of them are directly or indirectly connected to glutamatergic transmission.

One of them is adenomatous polyposis coli (APC) gene, coding a multifunctional protein widely expressed in neurons and glial cells throughout the brain. APC protein is involved in plethora of processes, such as regulation of axon outgrowth, neuronal differentiation, and radial glial polarity [133]. Its heterozygous deletion or polymorphism is associated with ASD [106, 134]. APC protein regulates, among others, the canonical Wnt/beta-catenin signaling pathway [135], which seems to be involved in development and maturation of BG, which occurs simultaneously with PC dendritogenesis and synaptogenesis [136]. It is worth mentioning that mutations in CTNNB1 (beta-catenin) or $W N T$ genes also are linked to this disease [137, 138].

Insight on the role of APC in the cerebellum was brought by Wang et al. [133] who proved the crucial and selective role of this protein in maintaining the morphology and function of BG. Mice in which APC gene was inactivated in GFAPexpressing cells showed marked abnormalities in BG morphology (but not in astrocytes in other parts of the brain). Since then, radial fibers of BG shortened significantly with a marked reduction of branching collaterals. BG bodies translocated into the molecular layer, loss the contact with the pia, and transformed into stellate-shaped cells. During middle age, PC loss was significant, especially in lobules VI, VII, and VIII where disruption of BG morphology was most severe (which actually overlap with the most disrupted lobules in neuropathology of autism [10]). Wang et al. [133] suppose that degeneration of PC is caused by deprivation of glial control of glutamate clearance.
Anomalies in BG found in mouse models are similar to those reported in study of Wegiel et al. [9]. In some of the autistic brains, they observed dispersion of BG somata within the molecular layer and total loss of its vertical fibers. Morphologically, these cells were similar to cortical astrocytes. Simultaneously, underdevelopment of PC was observed in dysplastic regions. Unfortunately, the genetic background of analyzed cases was not determined in this study. As far as we know, there is no postmortem studies evaluating BG in humans with disrupted APC.

\section{Conclusions}

Autism spectrum disorder can be caused by a variety of genetic and environmental factors, which concomitant action results in structural and functional abnormalities in various parts of the brain. In the cerebellum, the most marked pathological changes seen are underdevelopment or degeneration of PC. We have presented above data pointing to the hypothesis that abnormalities in PC can be caused by lack of appropriate support from BG. Like astrocytes, BG can protect PC from excitotoxicity by the clearance of glutamate. Moreover, cerebellar LTD (seen as a neuroprotective mechanism) requires BG to occur. Recent findings which revealed that disruption of BG functions leads to PC degeneration indicate a previously overlooked causative mechanism for ASD phenotypes. We suppose that therapies targeting BG can be efficient for treating some pathological features of ASD.

Acknowledgments The authors are very grateful to Mr. Jerzy Green, Mr. Szymon Jeziorko, Ms. E.J. Henly-Lewis, and Dr. Michal Slezak for their careful and critical reading of the paper.

\section{Compliance with Ethical Standards}

Financial Disclosures None to declare

Open Access This article is distributed under the terms of the Creative Commons Attribution 4.0 International License (http:// creativecommons.org/licenses/by/4.0/), which permits unrestricted use, distribution, and reproduction in any medium, provided you give appropriate credit to the original author(s) and the source, provide a link to the Creative Commons license, and indicate if changes were made.

\section{References}

1. Siuda K, Chrobak AA, Starowicz-Filip A et al (2014) Emotional disorders in patients with cerebellar damage-case studies. Psychiatr Pol 48:289-297

2. Koziol LF, Budding D, Andreasen N et al (2014) Consensus paper: the cerebellum's role in movement and cognition. Cerebellum 13:151-177. doi:10.1007/s12311-013-0511-x 
3. Chrobak AA, Siuda K, Tereszko A et al (2014) Psychiatric disorders and the cerebellar structure and functions - an overview of the latest research. Psychiatria 11:15-22

4. Wang SS-H, Kloth AD, Badura A (2014) The cerebellum, sensitive periods, and autism. Neuron 83:518-532. doi:10.1016/j. neuron.2014.07.016

5. Fatemi SH, Aldinger KA, Ashwood P et al (2012) Consensus paper: pathological role of the cerebellum in autism. Cerebellum 11:777-807. doi:10.1007/s12311-012-0355-9

6. Rybakowski F, Białek A, Chojnicka I et al (2014) Autism spectrum disorders - epidemiology, symptoms, comorbidity and diagnosis. Psychiatr Pol 48:653-665

7. Courchesne E, Yeung-Courchesne R, Press GA et al (1988) Hypoplasia of cerebellar vermal lobules VI and VII in autism. N Engl J Med 318:1349-1354

8. Courchesne E (1991) Neuroanatomic imaging in autism. Pediatrics 87:781-790

9. Wegiel J, Kuchna I, Nowicki K et al (2013) Contribution of olivofloccular circuitry developmental defects to atypical gaze in autism. Brain Res 1512:106-122. doi:10.1016/j.brainres.2013.03. 037

10. Becker EBE, Stoodley CJ (2013) Autism spectrum disorder and the cerebellum. Int Rev Neurobiol 113:1-34. doi:10.1016/B9780-12-418700-9.00001-0

11. Gerhant A, Olajossy M, Olajossy-Hilkesberger L (2013) Neuroanatomical, genetic and neurochemical aspects of infantile autism. Psychiatr Pol 47:1101-1111

12. Whitney ER, Kemper TL, Rosene DL et al (2009) Density of cerebellar basket and stellate cells in autism: evidence for a late developmental loss of Purkinje cells. J Neurosci Res 87:22452254. doi:10.1002/jnr.22056

13. Verkhratsky A, Reichenbach A (2010) Bergmann Glial Cells. In: Squire LR (ed) Encycl Neurosci, Elsevier Ltd., pp 161-171

14. Llinas R, Lang EJ, Welsh JP (1997) The cerebellum, LTD, and memory: alternative views. Learn Mem 3:445-455. doi:10.1101/ $\operatorname{lm} .3 .6 .445$

15. Buffo A, Rossi F (2013) Origin, lineage and function of cerebellar glia. Prog Neurobiol 109:42-63. doi:10.1016/j.pneurobio.2013. 08.001

16. $\mathrm{Xu} \mathrm{H}$, Yang $\mathrm{Y}$, Tang $\mathrm{X}$ et al (2013) Bergmann glia function in granule cell migration during cerebellum development. Mol Neurobiol 47:833-844. doi:10.1007/s12035-013-8405-y

17. Heinsen H (1977) Quantitative anatomical studies on the postnatal development of the cerebellum of the albino rat. Anat Embryol 218:201-218

18. Komuro Y, Fahrion JK, Foote KD et al (2013) Granule cell migration and differentiation. In: Manto M, Gruol DL, Schmahmann JD, Koibuchi NM, Rossi F (eds) Handb Cerebellum Cerebellar Disord., pp 107-126

19. Komuro H, Yacubova E (2003) Recent advances in cerebellar granule cell migration. Cell Mol Life Sci 60:1084-1098. doi:10. 1007/s00018-003-2248-z

20. Yacubova E, Komuro H (2002) Intrinsic program for migration of cerebellar granule cells in vitro. J Neurosci 22:5966-5981

21. Fisher M, Trimmer P, Ruthel G (1993) Bergmann glia require continuous association with Purkinje cells for normal phenotype expression. Glia 8:172-182. doi:10.1002/glia.440080305

22. Yamada K, Fukaya M, Shibata T et al (2000) Dynamic transformation of Bergmann glial fibers proceeds in correlation with dendritic outgrowth and synapse formation of cerebellar Purkinje cells. J Comp Neurol 418:106-120

23. Lin Y, Chen L, Lin C et al (2009) Neuron-derived FGF9 is essential for scaffold formation of Bergmann radial fibers and migration of granule neurons in the cerebellum. Dev Biol 329:44-54. doi:10. 1016/j.ydbio.2009.02.011
24. Mecklenburg N, Martinez-Lopez JE, Moreno-Bravo JA et al (2014) Growth and differentiation factor 10 (Gdf10) is involved in Bergmann glial cell development under shh regulation. Glia 62: 1713-1723. doi:10.1002/glia.22710

25. Eiraku M, Tohgo A, Ono K et al (2005) DNER acts as a neuronspecific notch ligand during Bergmann glial development. Nat Neurosci 8:873-880. doi:10.1038/nn1492

26. Saito S-Y, Takeshima H (2006) DNER as key molecule for cerebellar maturation. Cerebellum 5:227-231. doi:10.1080/ 14734220600632564

27. Verkhratsky A, Orkand RK, Kettenmann H (1998) Glial calcium: homeostasis and signaling function. Physiol Rev 78:99-141

28. Habbas S, Ango F, Daniel H, Galante M (2011) Purinergic signaling in the cerebellum: Bergmann glial cells express functional ionotropic P2X7 receptors. Glia 59:1800-1812. doi:10.1002/ glia.21224

29. Dieudonne S (2001) Book review: serotonergic neuromodulation in the cerebellar cortex: cellular, synaptic, and molecular basis. Neurosci 7:207-219. doi:10.1177/107385840100700306

30. Kulik A, Haentzsch A, Lückermann M et al (1999) Neuron-glia signaling via alpha(1) adrenoceptor-mediated $\mathrm{Ca}(2+)$ release in Bergmann glial cells in situ. J Neurosci 19:8401-8408

31. Kirischuk S, Tuschick S, Verkhratsky A, Kettenmann H (1996) Calcium signalling in mouse Bergmann glial cells mediated by alpha1-adrenoreceptors and $\mathrm{H} 1$ histamine receptors. Eur J Neurosci 8:1198-1208

32. Roda E, Coccini T, Acerbi D et al (2008) Cerebellum cholinergic muscarinic receptor (subtype-2 and -3) and cytoarchitecture after developmental exposure to methylmercury: an immunohistochemical study in rat. J Chem Neuroanat 35:285-294. doi:10. 1016/j.jchemneu.2008.01.003

33. Riquelme R, Miralles CP, De Blas AL (2002) Bergmann glia GABA(A) receptors concentrate on the glial processes that wrap inhibitory synapses. J Neurosci 22:10720-10730

34. Bishop GA, Tian J Bin, Boulant JA et al. (2005) Evidence that the CRF family of peptides modulates synaptic transmission in cerebellar circuits by altering membrane properties of neurons and Bergmann glia. Neurosci Abstr 31:(726.11)

35. Furuya S, Hiroe T, Ogiso N et al (2001) Localization of Endothelin-A and -B receptors during the postnatal development of rat cerebellum. Cell Tissue Res 305:307-324. doi:10.1007 s004410100386

36. Fauquier T, Chatonnet F, Picou F et al (2014) Purkinje cells and Bergmann glia are primary targets of the TR $\alpha 1$ thyroid hormone receptor during mouse cerebellum postnatal development. Development 141:166-175. doi:10.1242/dev.103226

37. Poblete-Naredo I, Guillem AM, Juárez C et al (2011) Brainderived neurotrophic factor and its receptors in Bergmann glia cells. Neurochem Int 59:1133-1144. doi:10.1016/j.neuint.2011. 10.002

38. Huang Z, Ohno N, Terada N et al (2013) Immunohistochemical detection of angiotensin II receptors in mouse cerebellum and adrenal gland using "in vivo cryotechnique". Histochem Cell Biol 140:477-490. doi:10.1007/s00418-013-1084-y

39. Hou Y, Choi J-S, Shin Y-J et al (2011) Expression of vascular endothelial growth factor receptor-3 mRNA in the developing rat cerebellum. Cell Mol Neurobiol 31:7-16. doi:10.1007/ s10571-010-9530-z

40. Noma S, Ohya-Shimada W, Kanai M et al (2012) Overexpression of HGF attenuates the degeneration of Purkinje cells and Bergmann glia in a knockin mouse model of spinocerebellar ataxia type 7. Neurosci Res 73:115-121. doi:10.1016/j.neures.2012. 03.001

41. Morara S, Rosina A, Provini L et al (2000) Calcitonin gene-related peptide receptor expression in the neurons and glia of developing 
rat cerebellum: an autoradiographic and immunohistochemical analysis. Neuroscience 100:381-391

42. Jackson AC, Rossiter JP, Lafon M (2006) Expression of Toll-like receptor 3 in the human cerebellar cortex in rabies, herpes simplex encephalitis, and other neurological diseases. J Neurovirol 12: 229-234. doi:10.1080/13550280600848399

43. Al-Ghoul WM, Herman MD, Dubocovich ML (1998) Melatonin receptor subtype expression in human cerebellum. Neuroreport 9: 4063-4068

44. Cowell RM, Silverstein FS (2003) Developmental changes in the expression of chemokine receptor CCR1 in the rat cerebellum. J Comp Neurol 457:7-23. doi:10.1002/cne.10554

45. Tanaka M (2014) The dendritic differentiation of Purkinje neurons: unsolved mystery in formation of unique dendrites. Cerebellum 14:227-230. doi:10.1007/s12311-014-0585-0

46. Hiraoka Y, Komine O, Nagaoka M et al (2013) Delta-like 1 regulates Bergmann glial monolayer formation during cerebellar development. Mol Brain 6:25. doi:10.1186/1756-6606-6-25

47. Meier F, Giesert F, Delic S et al (2014) FGF/FGFR2 signaling regulates the generation and correct positioning of Bergmann glia cells in the developing mouse cerebellum. PLoS One 9:e101124. doi:10.1371/journal.pone.0101124

48. Miller RF (2004) D-Serine as a glial modulator of nerve cells. Glia 47:275-283

49. Sasaki T, Beppu K, Tanaka KF et al (2012) Application of an optogenetic byway for perturbing neuronal activity via glial photostimulation. Proc Natl Acad Sci U S A 109:20720-20725. doi:10.1073/pnas.1213458109

50. Huang H, Barakat L, Wang D, Bordey A (2004) Bergmann glial GlyT1 mediates glycine uptake and release in mouse cerebellar slices. J Physiol 560:721-736. doi:10.1113/jphysiol.2004.067801

51. Barakat L, Bordey A (2002) GAT-1 and reversible GABA transport in Bergmann glia in slices. J Neuropshysiol 88:1407-1419

52. Barakat L, Wang D, Bordey A (2002) Carrier-mediated uptake and release of taurine from Bergmann glia in rat cerebellar slices. J Physiol 541:753-767. doi:10.1113/jphysiol.2001.015834

53. Vig PJS, Shao Q, Subramony SH et al (2009) Bergmann glial S100B activates myo-inositol monophosphatase 1 and colocalizes to Purkinje cell vacuoles in SCA1 transgenic mice. Cerebellum 8:231-244. doi:10.1007/s12311-009-0125-5

54. Albanito L, Reddy CE, Musti AM (2011) c-Jun is essential for the induction of Il-1 $\beta$ gene expression in in vitro activated Bergmann glial cells. Glia 59:1879-1890. doi:10.1002/glia.21244

55. Purcell AE, Jeon OH, Zimmerman AW et al (2001) Postmortem brain abnormalities of the glutamate neurotransmitter system in autism. Neurology 57:1618-1628. doi:10.1212/WNL.57.9.1618

56. Essa MM, Braidy N, Vijayan KR et al (2013) Excitotoxicity in the pathogenesis of autism. Neurotox Res 23:393-400. doi:10.1007/ s12640-012-9354-3

57. Kinnear Kern J (2003) Purkinje cell vulnerability and autism: a possible etiological connection. Brain Dev 25:377-382. doi:10. 1016/S0387-7604(03)00056-1

58. Lehre KP, Levy LM, Ottersen OP et al (1995) Differential expression of two glial glutamate transporters in the rat brain: quantitative and immunocytochemical observations. J Neurosci 15:18351853

59. Schmitt A, Asan E, Püschel B et al (1996) Expression of the glutamate transporter GLT1 in neural cells of the rat central nervous system: non-radioactive in situ hybridization and comparative immunocytochemistry. Neuroscience 71:989-1004

60. Schmitt A, Asan E, Püschel B, Kugler P (1997) Cellular and regional distribution of the glutamate transporter GLAST in the CNS of rats: nonradioactive in situ hybridization and comparative immunocytochemistry. J Neurosci 17:1-10
61. López-Bayghen E, Ortega A (2011) Glial glutamate transporters: new actors in brain signaling. IUBMB Life 63:816-823. doi:10. 1002/iub.536

62. Vandenberg RJ, Ryan RM (2013) Mechanisms of glutamate transport. Physiol Rev 93:1621-1657. doi:10.1152/physrev.00007. 2013

63. Lehre KP, Danbolt NC (1998) The number of glutamate transporter subtype molecules at glutamatergic synapses: chemical and stereological quantification in young adult rat brain. J Neurosci 18:8751-8757

64. Watase K, Hashimoto K, Kano M et al (1998) Motor discoordination and increased susceptibility to cerebellar injury in GLAST mutant mice. Eur J Neurosci 10:976-988

65. Takayasu Y, Iino M, Takatsuru Y et al (2009) Functions of glutamate transporters in cerebellar Purkinje cell synapses. Acta Physiol (Oxf) 197:1-12. doi:10.1111/j.1748-1716.2009.02019.x

66. Takayasu Y, Iino M, Shimamoto K et al (2006) Glial glutamate transporters maintain one-to-one relationship at the climbing fiberPurkinje cell synapse by preventing glutamate spillover. J Neurosci 26:6563-6572. doi:10.1523/JNEUROSCI.5342-05. 2006

67. Takayasu Y (2005) Differential roles of glial and neuronal glutamate transporters in Purkinje cell synapses. J Neurosci 25:87888793. doi:10.1523/JNEUROSCI.1020-05.2005

68. Takatsuru Y, Takayasu Y, Iino M et al (2006) Roles of glial glutamate transporters in shaping EPSCs at the climbing fiber-Purkinje cell synapses. Neurosci Res 54:140-148. doi:10.1016/j.neures. 2005.11.002

69. Tanaka K, Watase K, Manabe T et al (1997) Epilepsy and exacerbation of brain injury in mice lacking the glutamate transporter GLT-1. Science 276:1699-1702

70. Matsugami TR, Tanemura K, Mieda M et al (2006) From the cover: indispensability of the glutamate transporters GLAST and GLT1 to brain development. Proc Natl Acad Sci U S A 103: 12161-12166. doi:10.1073/pnas.0509144103

71. Takatsuru Y, Iino M, Tanaka K, Ozawa S (2007) Contribution of glutamate transporter GLT-1 to removal of synaptically released glutamate at climbing fiber-Purkinje cell synapses. Neurosci Lett 420:85-89. doi:10.1016/j.neulet.2007.04.062

72. Martínez D, García L, Aguilera J, Ortega A (2014) An acute glutamate exposure induces long-term down regulation of GLAST/EAAT1 uptake activity in cultured Bergmann glia cells. Neurochem Res 39:142-149. doi:10.1007/s11064-013-1198-6

73. Gegelashvili M, Rodriguez-Kern A, Sung L et al (2007) Glutamate transporter GLAST/EAAT1 directs cell surface expression of FXYD2/gamma subunit of Na, K-ATPase in human fetal astrocytes. Neurochem Int 50:916-20. doi:10.1016/j.neuint.2006. 12.015

74. Duan S, Anderson CM, Stein BA, Swanson RA (1999) Glutamate induces rapid upregulation of astrocyte glutamate transport and cell-surface expression of GLAST. J Neurosci 19:10193-10200

75. Douyard J, Shen L, Huganir RL, Rubio ME (2007) Differential neuronal and glial expression of Glur1 AMPA receptor subunit and the scaffolding proteins SAP97 and 4.1N during rat cerebellar development. J Comp Neurol 502:141-156

76. Iino M, Goto K, Kakegawa W et al (2001) Glia-synapse interaction through $\mathrm{Ca} 2+$-permeable AMPA receptors in Bergmann glia. Science 292:926-929. doi:10.1126/science.1058827

77. Ishiuchi S, Tsuzuki K, Yamada N et al (2001) Extension of glial processes by activation of $\mathrm{Ca} 2+$-permeable AMPA receptor channels. Neuroreport 12:745-748

78. Saab AS, Neumeyer A, Jahn HM et al (2012) Bergmann glial AMPA receptors are required for fine motor coordination. Science 337:749-753. doi:10.1126/science.1221140 
79. Muller T, Moller T, Berger T et al (1992) Calcium entry through kainate receptors and resulting potassium-channel blockade in Bergmann glial cells. Science 256:1563-1566

80. Müller T, Möller T, Neuhaus J, Kettenmann H (1996) Electrical coupling among Bergmann glial cells and its modulation by glutamate receptor activation. Glia 17:274-284. doi:10.1002/(SICI) 1098-1136(199608)17:4<274::AID-GLIA2>3.0.CO;2-\#

81. López-Bayghen E, Espinoza-Rojo M, Ortega A (2003) Glutamate down-regulates GLAST expression through AMPA receptors in Bergmann glial cells. Brain Res Mol Brain Res 115:1-9

82. Matsui K, Jahr CE (2003) Ectopic release of synaptic vesicles. Neuron 40:1173-83

83. Matsui K, Jahr CE (2004) Differential control of synaptic and ectopic vesicular release of glutamate. J Neurosci 24:8932-9. doi:10.1523/JNEUROSCI.2650-04.2004

84. Matsui K, Jahr CE, Rubio ME (2005) High-concentration rapid transients of glutamate mediate neural-glial communication via ectopic release. J Neurosci 25:7538-7547. doi:10.1523/ JNEUROSCI.1927-05.2005

85. Balakrishnan S, Jackson C, Russell N, Bellamy TC (2011) Ectopic release sites lack fast vesicle recycling mechanisms, causing longterm depression of neuron-glial transmission in rat cerebellum. Glia 59:82-93. doi:10.1002/glia.21078

86. Balakrishnan S, Bellamy TC (2009) Depression of parallel and climbing fiber transmission to Bergmann glia is input specific and correlates with increased precision of synaptic transmission. Glia 57:393-401. doi:10.1002/glia.20768

87. Ito M (2002) The molecular organization of cerebellar long-term depression. Nat Rev Neurosci 3:896-902. doi:10.1038/nrn962

88. Hartell NA (1996) Strong activation of parallel fibers produces localized calcium transients and a form of LTD that spreads to distant synapses. Neuron 16:601-610

89. Palay SL, Chan-Palay V (1974) Cerebellar cortex: cytology and organization. Springer, Verlag, Berlin, Heidelberg

90. Fox CA, Barnard JW (1957) A quantitative study of the purkinje cell dendritic branchlets and their relationship to afferent fibres. J Anat 91:299-313

91. Welsh JP, Yamaguchi H, Zeng X-H et al (2005) Normal motor learning during pharmacological prevention of Purkinje cell longterm depression. Proc Natl Acad Sci U S A 102:17166-17171. doi:10.1073/pnas.0508191102

92. Schonewille M, Gao Z, Boele H-J et al (2011) Reevaluating the role of LTD in cerebellar motor learning. Neuron 70:43-50. doi: 10.1016/j.neuron.2011.02.044

93. Ito M (2006) Cerebellar circuitry as a neuronal machine. Prog Neurobiol 78:272-303. doi:10.1016/j.pneurobio.2006.02.006

94. Shibuki K, Gomi H, Chen L et al (1996) Deficient cerebellar longterm depression, impaired eyeblink conditioning, and normal motor coordination in GFAP mutant mice. Neuron 16:587-599

95. Hughes EG, Maguire JL, McMinn MT et al (2004) Loss of glial fibrillary acidic protein results in decreased glutamate transport and inhibition of PKA-induced EAAT2 cell surface trafficking. Brain Res Mol Brain Res 124:114-123. doi:10.1016/j. molbrainres.2004.02.021

96. Dehnes Y, Chaudhry FA, Ullensvang K et al (1998) The glutamate transporter EAAT4 in rat cerebellar Purkinje cells: a glutamategated chloride channel concentrated near the synapse in parts of the dendritic membrane facing astroglia. J Neurosci 18:36063619

97. Tsai M-C, Tanaka K, Overstreet-Wadiche L, Wadiche JI (2012) Neuronal glutamate transporters regulate glial excitatory transmission. J Neurosci 32:1528-1535. doi:10.1523/JNEUROSCI.523211.2012

98. Yamashita A, Makita K, Kuroiwa T, Tanaka K (2006) Glutamate transporters GLAST and EAAT4 regulate postischemic Purkinje cell death: an in vivo study using a cardiac arrest model in mice lacking GLAST or EAAT4. Neurosci Res 55:264-270. doi:10. 1016/j.neures.2006.03.007

99. Wadiche JI, Jahr CE (2005) Patterned expression of Purkinje cell glutamate transporters controls synaptic plasticity. Nat Neurosci 8: 1329-1334. doi:10.1038/nn1539

100. Su L-D, Shen Y (2009) Blockade of glutamate transporters facilitates cerebellar synaptic long-term depression. Neuroreport 20: 502-507. doi:10.1097/WNR.0b013e328328f397

101. Alba A, Kano M, Chen C et al (1994) Deficient cerebellar longterm depression and impaired motor learning in mGluR1 mutant mice. Cell 79:377-388

102. Brasnjo G, Otis TS (2001) Neuronal glutamate transporters control activation of postsynaptic metabotropic glutamate receptors and influence cerebellar long-term depression. Neuron 31:607616. doi:10.1016/S0896-6273(01)00377-4

103. Schaaf CP, Sabo A, Sakai Y et al (2011) Oligogenic heterozygosity in individuals with high-functioning autism spectrum disorders. Hum Mol Genet 20:3366-3375. doi:10.1093/hmg/ddr243

104. Lossifov I, Ronemus M, Levy D et al (2012) De novo gene disruptions in children on the autistic spectrum. Neuron 74:285-299. doi:10.1038/nature11130.Reduced

105. Barber JC, Ellis KH, Bowles LV et al (1994) Adenomatous polyposis coli and a cytogenetic deletion of chromosome 5 resulting from a maternal intrachromosomal insertion. J Med Genet 31:312-316. doi:10.1136/jmg.31.4.312

106. Zhou X-L, Giacobini M, Anderlid B-M et al (2007) Association of adenomatous polyposis coli (APC) gene polymorphisms with autism spectrum disorder (ASD). Am J Med Genet B Neuropsychiatr Genet 144B:351-354. doi:10.1002/ajmg.b.30415

107. Kyzar EJ, Pham M, Roth A et al (2012) Alterations in grooming activity and syntax in heterozygous SERT and BDNF knockout mice: the utility of behavior-recognition tools to characterize mutant mouse phenotypes. Brain Res Bull 89:168-176. doi:10.1016/ j.brainresbull.2012.08.004

108. Nelson KB, Grether JK, Croen LA et al (2001) Neuropeptides and neurotrophins in neonatal blood of children with autism or mental retardation. Ann Neurol 49:597-606. doi:10.1002/ana.1024

109. Wang K, Zhang H, Ma D et al (2009) Common genetic variants on 5 p14.1 associate with autism spectrum disorders. Nature 459:528 533. doi:10.1038/nature07999

110. Fatemi SH, Snow AV, Stary JM et al (2005) Reelin signaling is impaired in autism. Biol Psychiatry 57:777-787. doi:10.1016/j. biopsych.2004.12.018

111. Vaags AK, Lionel AC, Sato D et al (2012) Rare deletions at the neurexin 3 locus in autism spectrum disorder. Am J Hum Genet 90:133-141. doi:10.1016/j.ajhg.2011.11.025

112. Brune CW, Kim S, Hanna GL et al (2008) Family-based association testing of OCD-associated SNPS of SLC1A1 in an autism sample. Autism Res 1:108-113. doi:10.1002/aur.11.Family-Based

113. Edvardson S, Ashikov A, Jalas C et al (2013) Mutations in SLC35A3 cause autism spectrum disorder, epilepsy and arthrogryposis. J Med Genet 50:733-739. doi:10.1136/ jmedgenet-2013-101753

114. Vourc'h P, Martin I, Bonnet-Brilhault F et al (2003) Mutation screening and association study of the UBE2H gene on chromosome 7q32 in autistic disorder. Psychiatr Genet 13:221-225. doi: 10.1097/00041444-200312000-00005

115. Prasad a., Merico D, Thiruvahindrapuram B et al. (2012) A discovery resource of rare copy number variations in individuals with autism spectrum disorder. G3 Genes|Genomes|Genetics 2:16651685. doi: $10.1534 / \mathrm{g} 3.112 .004689$

116. Bruno DL, Anderlid B-M, Lindstrand A et al (2010) Further molecular and clinical delineation of co-locating $17 \mathrm{p} 13.3$ microdeletions and microduplications that show distinctive phenotypes. J Med Genet 47:299-311. doi:10.1136/jmg.2009.069906 
117. Koirala S, Corfas G (2010) Identification of novel glial genes by single-cell transcriptional profiling of Bergmann glial cells from mouse cerebellum. PLoS One 5:e9198. doi:10.1371/journal.pone. 0009198

118. Kohda K, Kakegawa W, Matsuda S et al (2013) The $\delta 2$ glutamate receptor gates long-term depression by coordinating interactions between two AMPA receptor phosphorylation sites. Proc Natl Acad Sci U S A 110:E948-57. doi:10.1073/pnas.1218380110

119. Kakegawa W, Miyoshi Y, Hamase K et al (2011) D-Serine regulates cerebellar LTD and motor coordination through the $\delta 2$ glutamate receptor. Nat Neurosci 14:603-611. doi:10.1038/nn.2791

120. Kim PM, Aizawa H, Kim PS et al (2005) Serine racemase: activation by glutamate neurotransmission via glutamate receptor interacting protein and mediation of neuronal migration. Proc Natl Acad Sci U S A 102:2105-2110. doi:10.1073/pnas. 0409723102

121. Zimmerman AW, Hubner KF, Frye VH (1990) Ketamine anesthesia for MRI and PET in children with autism: behavioral responses and reduced cerebellar glucose utilization. Neurology 40(suppl): 359

122. Hassan TH, Abdelrahman HM, Abdel Fattah NR et al (2013) Blood and brain glutamate levels in children with autistic disorder. Res Autism Spectr Disord 7:541-548. doi:10.1016/j.rasd.2012. 12.005

123. Fatemi SH, Halt AR, Stary JM et al (2002) Glutamic acid decarboxylase 65 and $67 \mathrm{kDa}$ proteins are reduced in autistic parietal and cerebellar cortices. Biol Psychiatry 52:805-810

124. Shen L, Liang F, Walensky LD, Huganir RL (2000) Regulation of AMPA receptor GluR1 subunit surface expression by a $4.1 \mathrm{~N}$ linked actin cytoskeletal association. J Neurosci 20:7932-7940

125. Allen G (2005) The cerebellum in autism. Clin Neuropsychiatry 2: 321-337

126. Bauman M, Kemper T (2005) Neuroanatomic observations of the brain in autism: a review and future directions. Int J Dev Neurosci 23:183-187

127. Bailey A, Luthert P, Dean A et al (1998) A clinicopathological study of autism. Brain 121:889-905
128. Singh VK, Warren R, Averett R, Ghaziuddin M (1997) Circulating autoantibodies to neuronal and glial filament proteins in autism. Pediatr Neurol 17:88-90

129. Edmonson C, Ziats MN, Rennert OM (2014) Altered glial marker expression in autistic post-mortem prefrontal cortex and cerebellum. Mol Autism 5:3. doi:10.1186/2040-2392-5-3

130. Ahlsen G, Rosengren L, Belfrage M et al (1993) Glial fibrillary acidic protein in the cerebrospinal fluid of children with autism and other neuropsychiatric disorders. Biol Psychiatry 33:734-743

131. Fatemi SH, Folsom TD, Reutiman TJ, Lee S (2008) Expression of astrocytic markers aquaporin 4 and connexin 43 is altered in brains of subjects with autism. Synapse 62:501-507. doi:10.1002/syn. 20519

132. Iliff JJ, Wang M, Liao Y et al (2012) A paravascular pathway facilitates CSF flow through the brain parenchyma and the clearance of interstitial solutes, including amyloid. Sci Transl Med 4: 147ra111. doi:10.1126/scitranslmed.3003748

133. Wang X, Imura T, Sofroniew MV, Fushiki S (2011) Loss of adenomatous polyposis coli in Bergmann glia disrupts their unique architecture and leads to cell nonautonomous neurodegeneration of cerebellar purkinje neurons. Glia 59:857-868. doi:10.1002/glia. 21154

134. Heald B, Moran R, Milas M et al (2007) Familial adenomatous polyposis in a patient with unexplained mental retardation. Nat Clin Pract Neurol 3:694-700. doi:10.1038/ncpneuro0658

135. Kinzler KW, Nilbert MC, Su LK et al (1991) Identification of FAP locus genes from chromosome 5q21. Science 253:661-665

136. Selvadurai HJ, Mason JO (2011) Wnt/ $\beta$-catenin signalling is active in a highly dynamic pattern during development of the mouse cerebellum. PLoS One 6:e23012. doi:10.1371/journal.pone. 0023012

137. Mohn JL, Alexander J, Pirone A et al. (2014) Adenomatous polyposis coli protein deletion leads to cognitive and autism-like disabilities. Mol Psychiatry 1-10. doi: 10.1038/mp.2014.61

138. Krumm N, O’Roak BJ, Shendure J, Eichler EE (2014) A de novo convergence of autism genetics and molecular neuroscience. Trends Neurosci 37:95-105. doi:10.1016/j.tins.2013.11.005 